Wilfrid Laurier University

Scholars Commons @ Laurier

Political Science Faculty Publications

Political Science

$9-1-1986$

\title{
Human Dignity, Human Rights, and Political Regimes
}

Rhoda E. Howard-Hassmann

Wilfrid Laurier University, hassmann@wlu.ca

Jack Donnelly

University of North Carolina Chapel Hill

Follow this and additional works at: https://scholars.wlu.ca/poli_faculty

\section{Recommended Citation}

Howard-Hassmann, Rhoda E. and Donnelly, Jack, "Human Dignity, Human Rights, and Political Regimes" (1986). Political Science Faculty Publications. 19.

https://scholars.wlu.ca/poli_faculty/19

This Article is brought to you for free and open access by the Political Science at Scholars Commons @ Laurier. It has been accepted for inclusion in Political Science Faculty Publications by an authorized administrator of Scholars Commons@ Laurier. For more information, please contact scholarscommons@wlu.ca. 


\begin{tabular}{c}
\hline HUMAN DIGNITY, \\
HUMAN RIGHTS, \\
AND POLITICAL \\
REGIMES \\
\hline RHODA E. HOWARD \\
McMaster University \\
JACK DONNELLY \\
University of North Carolina \\
Chapel Hill \\
\hline
\end{tabular}

$I_{t}$ is often argued that internationally recognized human rights are common to all cultural traditions and adaptable to a great variety of social structures and political regimes. Such arguments confuse human rights with human dignity. All societies possess conceptions of human dignity, but the conception of human dignity underlying international human rights standards requires a particular type of "liberal" regime. This conclusion is reached through a comparison of the social structures of ideal type liberal, minimal, traditional, communist, corporatist and developmental regimes and their impact on autonomy, equality, privacy, social conflict, and the definition of societal membership.

\section{$T_{\text {he international }}$} human rights elaborated in the Universal Declaration of Human Rights and the International Human Rights Covenants often are held to be compatible with a great variety of political regimes. For example, Khushalani $(1983$, p. 404) argues that "the concept of human rights can be traced to the origin of the human race itself," and that "all the philosophies of our time" are committed to human rights. Likewise, Graefrath (1983, p. 6) argues that international human rights standards "can be adapted to any legal system" (cf. Buultjens, 1980; Gros Espiell, 1979; Marasinghe, 1984; Mojekwu, 1980; Pollis, 1982; Ruffin, 1982; Stackhouse, 1984; Wiarda, 1982). We argue, however, that international human rights standards are based on a distinctive substantive conception of human dignity. They therefore require a particular type of "liberal" regime, which may be institutionalized in various forms, but only within a relatively narrow range of variation. The authors cited above confuse human rights with human dignity.

"Human dignity" figures prominently in international human rights documents; for example, the International Human Rights Covenants proclaim that human rights "derive from the inherent dignity of the human person" (1966). Furthermore, every form of political regime implicitly reflects a particular social conception of human dignity. Nonetheless, human rights and human dignity are quite distinct notions.

\section{AMERICAN POLITICAL SCIENCE REVIEW VOL. 80 NO. 3 SEPTEMBER, 1986}




\section{American Political Science Review Vol. 80}

Conceptions of human dignity, in their social and political aspects, express particular understandings of the inner (moral) nature and worth of the human person and his or her proper (political) relations with society. Human rights, by contrast, are the equal and inalienable rights, in the strong sense of entitlements that ground particularly powerful claims against the state, that each person has simply as a human being. Human rights are a particular social practice that aims to realize a distinctive substantive conception of human dignity (Donnelly, 1982a). Conceptions of human dignity vary dramatically across societies, and most of these variations are incompatible with the values of equality and autonomy that underlie human rights. Most regimesand their underlying social conceptions of human dignity-necessarily deny both the idea and the practice of human rights.

In order to examine the relations between human rights and conceptions of human dignity across a wide range of regimes, our analysis relies heavily on the use of ideal types-"the construction of certain elements of reality into a logically precise conception" (Weber, 1946, p. 59)-especially ideal-type conceptions of the human person and his or her obligations to and claims upon society and the state. We first specify the philosophical and structural connections between the "liberal" conception of human dignity and the principle and practice of human rights. Then we show how four major contemporary regime types; which we call communitarian, necessarily repudiate human rights because of their commitment to alternative social conceptions of human dignity.

The particular interpretation of liberalism we adopt provides the philosophical and structural basis for international human rights norms. This is not a paper on liberal theory. In another context we would argue for the authenticity of our interpretation, but here we claim only that it is a plausible, standard reading of the liberal tradition. Our subject in this article is human rights, not liberalism. Therefore, even if our definition should prove to be stipulative, the substance of our argument, which focuses on the social and political requirements of human rights, would remain largely unaffected.

We should also note that we do not join arguments about the content of lists of human rights. Instead, as is common in the human rights literature, we accept the list in the Universal Declaration of Human Rights without argument. In particular, we avoid rehashing old arguments about economic and social rights. Both on theoretical grounds (see Donnelly, 1982b; Donnelly, 1985, ch. 6; Shue, 1980, pt. 1). and in light of the nearly universal official acceptance of the Universal Declaration, we adopt the full list of rights it provides, with civil, political, economic, and social rights on an equal footing.

While these two simplifying assumptions narrow our focus, our argument remains significant and controversial. We contend that internationally recognized human rights require a liberal regime. Other types of regimes, and the conceptions of human dignity on which they rest, may be defensible on other moral or political grounds, but they will not stand up to scrutiny under the standard of human rights.

\section{Liberalism and Human Rights: A Necessary Connection}

\section{Liberalism, Equality, and Personal Autonomy}

We follow Ronald Dworkin (1977, ch. 12; 1985, ch. 8) in arguing that the heart of liberalism is expressed in the basic political right to equal concern and respect:

Government must treat those whom it governs with concern, that is, as human beings who are capable of suffering and frustration, and with respect, that is, as human beings who are capable 


\section{Human Dignity, Human Rights, Political Regimes}

of forming and acting on intelligent conceptions of how their lives should be lived. Government must not only treat people with concern and respect, but with equal concern and respect. It must not distribute goods or opportunities unequally on the ground that some citizens are entitled to more because they are worthy of more concern. It must not constrain liberty on the ground that one citizen's conception of the good life .... is nobler or superior to another's. (Dworkin, 1977, p. 273)

The state must treat each person as a moral and political equal-not assure each an equal share of social resources, but treat all with equal concern and respect. Inequalities in goods or opportunities that arise directly or indirectly from political decisions-and many such inequalities are easily justified within a liberal regime-must be compatible with the right to equal concern and respect.

Personal liberty, especially the liberty to choose and lead one's own life, clearly is entailed by the principle of equal respect: for the state to interfere in matters of personal morality would be to treat the life plans and values of some as superior to others. A certain amount of economic liberty is also required, at least to the extent that decisions concerning consumption, investment, and risk reflect free decisions based on personal values that arise from autonomously chosen conceptions of the good life. Liberty alone, however, cannot serve as the overriding value of social life, as the end to be maximized by political association.

Liberty readily degenerates into license and social atomization unless checked by a fairly expansive, positive conception of the persons in relation to whom it is exercised. If liberty is to foster dignity, it must be exercised within the constraints of the principle of equal concern and respect. In fact, autonomy and equality are less a pair of guiding principles than different manifestations of the central liberal commitment to the equal worth and dignity of each and every person.

Each human being is of equal moral worth individually, whatever his or her social utility. Individuals-regardless of who they are or where they stand-have an inherent dignity and moral worth that the state must not merely passively respect, but for which it must demonstrate an active concern. Furthermore, everyone is entitled to this equal concern and respect. Minimum standards of political treatment are embodied in (human) rights; they are not merely desirable goals of social policy. This implies a particular conception of the relation of the individual to the community and the state.

Man is a social animal; human potential, and even personal individuality, can be developed and expressed only in a social context. Society requires the discharge of certain political functions, and large-scale political organization requires the state. However, the state-especially the modern state-also presents particularly serious threats to human dignity. The state is easily turned to the denial of equal concern and respect, through the enforcement of a particular vision of the good life or the entrenchment of privileged inequality. Therefore, human rights have a special reference to the state, in order to keep it an instrument to realize, rather than undermine, equal concern and respect. In the inevitable conflicts between the individual and the state, the liberal gives prima facie priority, in the areas protected by human rights, to the individual.

For the liberal, the individual is not merely separable from the community and social roles, but specially valued precisely as a distinctive, discrete individual-which is why each person must be treated with equal concern and respect. The state and society are conceived, in more or less contractarian terms, as forms of association for the fuller unfolding of human potential, through the exercise and enjoyment of human rights. Human dignity, for the liberal, is largely encompassed in the vision of life as an equal and autonomous member of society, enjoying a full range of human rights. 


\section{American Political Science Review Vol. 80}

This liberal view of man is rooted in structural changes that began to emerge in late medieval and early modern Europe, gained particular force in the eighteenth and nineteenth centuries, and today are increasingly the norm throughout the world. The "creation" of the private individual separate from society is closely linked to the rise of a new, more complex division of labor, the resulting changes in class structure (particularly the rise and then dominance of the bourgeoisie), and a new vision of the individual's relationship to God, society, and the state.

These developments are well known, and need not be recounted here. For our purposes, though, it is important to stress that in the social changes of modernization-especially migration, urbanization, and technological development-the allencompassing moral whole of traditional or feudal society was replaced by a much more segmented social order. In particular, politics was separated from religion, the economy, and law, which were likewise separated from one another. Individuals, too, were separated from society as a whole; no longer could persons be reduced to their roles, to parts of the community. With separate individuals, possessing special worth and dignity precisely as individuals, the basis for human rights was established.

Occurring parallel to these changes in society was the equally well-known development of the modern state. The new bourgeois class was initially a principal backer of the newly rising princes and kings and their states; both shared an interest in freeing themselves from the constraints of the old feudal order. However, as the modern state's power grew, it increasingly threatened the individual citizen. Bourgeois "freemen" began to demand, therefore, that they indeed be free. Such demands eventually took the form of arguments for the universal natural rights and equality of all men. In the new socially mobile society, in which entrance to and exit from the bourgeois class was relatively unpredictable, a new set of privileges could not readily be reserved for a new elite defined by birth or some similar characteristic. Rather, in order that some (the bourgeoisie) might be able to exercise these new rights, they had to be guaranteed for all.

Thus, human rights came to be articulated primarily as claims of any individual against the state. Human rights lay down the basic form of the relationship between the (new, modern) individual and the (new, modern) state, a relationship based on the prima facie priority of the individual over the state in those areas protected by human rights. Human rights are viewed as (morally) prior to and above society and the state, and under the control of individuals, who hold them and may exercise them against the state in extreme cases. This reflects not only the equality of all individuals, but also their autonomy - their right to have and pursue interests and goals different from those of the state or its rulers. In the areas and endeavors protected by human rights, the individual is "king," or rather, an equal and autonomous person entitled to equal concern and respect.

In practice, of course, these values and structural changes remain incompletely realized even today, and for most of the modern era they have been restricted to a small segment of the population. Nonetheless, the ideal was established and its implementation begun. Even if the demand for human rights began as a tactic of the bourgeoisie to protect its own class interests, the logic of universal, inalienable personal rights has long since broken free of these origins.

Furthermore, while these processes of sociopolitical individuation and state building were first played out in Europe, they are increasingly the rule throughout the world. As a result, the structural basis for a society of equal and autonomous in- 


\section{Human Dignity, Human Rights, Political Regimes}

dividuals is being universalized. Social structure today increasingly parallels the near universal diffusion of the idea of human rights and the philosophical claim that human rights are universal. Individual human rights, therefore, increasingly appear not merely as moral ideals, but as both objectively and subjectively necessary to protect and realize human dignity (cf. Howard, 1986).

\section{Liberalism and International Human Rights}

The standard list of human rights in the Universal Declaration of Human Rights can be easily derived from the liberal conception of the individual and the state. Other lists, of course, have been and may be derived from these principles, but we would argue that the near perfect fit between liberalism and the Universal Declaration reflects a deep and essential theoretical connection.

To be treated with concern and respect, whether equal or unequal, requires prior recognition of the individual as a moral and legal person, which in turn requires certain basic personal rights. Rights to recognition before the law and to nationality (Universal Declaration, Articles 6, 15) are prerequisites to political treatment as a person. In a somewhat different vein, the right to life, as well as rights to protection against slavery, torture, and other inhuman or degrading treatment (Articles 3 , $4,5)$ are essential to recognition and respect as a person.

Rights such as freedoms of speech, conscience, religion, and association (Articles 18 , 19) protect a sphere of personal autonomy. The right to privacy (Article 12) even more explicitly aims to guarantee the capacity to realize personal visions of a life worthy of a human being. Personal autonomy also requires economic and social rights, such as the right to education (Article 26), which provides the intellectual resources for informed autonomous choices and the skills needed to act on them, and the right to participate in the cultural life of the community (Article 27), which recognizes the social and cultural dimensions of personal development. In its political dimension, equal respect also implies democratic control of the state, and thus rights to vote and to freedoms of (political) speech, press, assembly, and association (Articles 19, 20, 21).

The principle of equal concern and respect also requires the government to intervene to reduce social and economic inequalities that deny equal personal worth. The state must actively intervene to protect those who, as a result of natural or voluntary membership in an unpopular group, are subject to social, political, or economic discrimination that limits their access to a fair share of social resources or opportunities. Rights such as equal protection of the laws and protection against discrimination on such bases as race, color, sex, language, religion, opinion, origin, property, birth, or status (Articles $2,7)$ are essential to assure that all people are treated as fully and equally human.

In the economic sphere, the traditional liberal attachment to the market is not accidental: quite aside from its economic efficiency, the market places minimal restraints on economic liberty, and thus maximizes personal autonomy. However, market distribution of resources can have grossly unequal outcomes. Inequality per se is not objectionable to the liberal, but the principle of equal concern and respect does imply a floor of basic economic welfare; degrading inequalities (Shue, 1980, pp. 119-23) cannot be permitted. The state also has an appropriate interest in redressing market-generated inequalities because a "free market" system of distributing resources is actively backed by the state, which protects and enforces property rights.

Differential market rewards are not neutral; they reward morally equal individuals unequally. Market distributions 


\section{American Political Science Review Vol. 80}

may be substantially affected by such morally irrelevant factors as race, sex, class, or religion, while many of the "talents" richly rewarded by the market are of dubious moral significance. Even "achieved" inequalities, should they threaten the (moral) equality or autonomy of other citizens, present at least a prima facie case for state intervention. The principle of equal concern and respect requires the state to act positively to cancel unjustifiable market inequalities, at least to the point that all are assured a minimum share of resources through the implementation of social and economic rights. In human rights terms, this implies, for example, rights to food, health care, and social insurance (Articles 22, 25).

Efforts to alleviate degrading or disrespectful misery and deprivation do not exhaust the scope of the economic demands of the principle of equal concern and respect. The right to work (Article 23), which is essentially a right to economic participation, is of especially great importance. It has considerable intrinsic value: work is essential to a life of dignity, insofar as man is conceived as homo faber. It also has great instrumental value, both for the satisfaction of basic material needs and for providing a secure and dignified economic foundation from which to pursue personal values and objectives. A (limited) right to property (Article 17) can be justified in similar terms.

Finally, the special threat to personal autonomy and equality presented by the modern state requires a set of legal rights such as the presumption of innocence and rights to due process, fair and public hearings before an independent tribunal, and protection from arbitrary arrest, detention, or exile (Articles 8-11). More broadly, the special threat to dignity posed by the state is reflected in the fact that all human rights are held particularly against the state. Moreover, they hold against all types of states, democratic as much as any other: if one's government treats one as less than fully human, it matters little, if at all, how that government came to power. The individual of course has social duties (Article 29), but the discharge of social obligations is not a precondition for having or exercising human rights.

We have thus moved from the liberal principle of equal concern and respect to the full list of human rights in the Universal Declaration. These rights, in turn, demand-and if implemented would play a crucial role in creating - a liberal society, and the ideal person envisioned by liberalism (cf. Donnelly, 1985, ch. 3). It would be equally simple to work back from the Universal Declaration to the principle of equal concern and respect. In fact, the association between liberalism and human rights runs so deep that the realization of human rights is the principal liberal standard for evaluating the achievements, and even the legitimacy, of any regime (cf. Donnelly, 1985, pp. 69-73).

\section{Liberalism vs. the Minimal State}

In practice, obviously, even the best of actual liberal regimes fall short of the ideal we have been discussing, and the human rights records of many selfprofessed liberal societies merit severe criticism. Furthermore, many avowed liberals view liberty and equality as largely antagonistic principles to be traded off against one another, rather than as complementary dimensions of the single principle of equal concern and respect. One way to make this tradeoff is to choose liberty and disregard equality, establishing a "minimal" or "nightwatchman" regime.

Advocates of the minimal state (e.g., Nozick, 1974) would largely limit the state to protecting public order and private property. To assure the good behavior of the nightwatchman, "nega- 


\section{Human Dignity, Human Rights, Political Regimes}

tive" civil and political rights are also required, especially civil liberties, narrowly conceived as rights to public noninterference in the private lives (very broadly understood) of individuals. Yet minimalism also explicitly protects property rights while rejecting economic and social human rights. Beyond minimalism's obvious incompatibility with international human rights standards (which minimalists readily allow), its deep commitment to protecting private property while denying all other economic and social rights borders on logical contradiction; we can see no way that precisely and only this one economic right can justifiably be allowed on the minimalist's list of human rights.

The standard rights-based (i.e., not merely utilitarian) arguments for the right to private property in such contexts rest on the importance of guaranteed private economic activity. and resources for the enjoyment of personal autonomy. Clearly, however, such an argument does not justify a right to unlimited individual accumulation: at a certain point, additional economic resources contribute nothing at all to personal autonomy, and long before that point the marginal return becomes vanishingly small. Even more importantly, exactly the same argument can be made for other social and economic rights. In fact, a substantially stronger case can be made for rights to work, a minimum standard of living, and health care.

In any case, the minimal state is almost certain to be self-destructing if it recognizes equal, universal civil and political rights. The denial of political participation usually rests on a desire to protect social and economic privilege, while those previously excluded from political participation tend to use their newly acquired power to obtain a fair, or at least a tolerable, share of social resources (cf. Goldstein, 1983). The emergence of the Western welfare state and popular pressure throughout the Third World for social services clearly suggests that implementing equal, universal political rights will transform a minimal regime.

The only way to avoid this would be to entrench a right to private property against the exercise of all other human rights. This is obviously unjustifiable; no plausible theory of human nature or dignity yields this one right as superior to all other human rights. However, lesser entrenchment, allowing redistribution beyond a certain level of accumulation, would be ineffective. If the point beyond which redistribution would take place were set democratically, a minimal regime would almost certainly be democratically abolished, or at least dismantled over time. Any other way of setting the limit, however, would deny the equality of political rights.

In other words, the minimal state, in its very essence, is a violator of human rights, even within the limits of its own terms of reference. Liberalism's dual pursuit of autonomy and equality is replaced in minimalism by a single-minded pursuit of autonomy understood largely as the social guarantee of the broadest possible sphere of private action, virtually irrespective of its social consequences. For the minimalist, human dignity is expressed principally in the unequal, achieved consequences of private, largely conflictual, action.

The minimal state thus is not the pure form of liberalism it is often represented to be by both minimalists and various leftist critics of liberalism. Rather, it is a perverse and internally inconsistent narrowing of liberalism that is also inconsistent with international human rights standards.

\section{Equality, Autonomy and Communitarian Societies}

Having shown that human rights and liberal regimes are closely matched, it re- 
mains to be shown that other types of regimes are incompatible with the demands of human rights, a task that we have begun with the discussion above of the minimal state. In this section we examine four major types of communitarian society, which together encompass the vast majority of contemporary nonliberal regimes.

We define communitarian societies as those that give ideological and practical priority to the community (sometimes embodied in the state) over the individual. Such societies regard their members as worthy of concern and respect, but only as members of society performing prescribed roles. Their concepts of human dignity, therefore, are not rooted in the notion of human rights. Communitarian societies are antithetical to the implementation and maintenance of human rights, because they deny the autonomy of the individual, the irreducible moral equality of all individuals, and the possibility of conflict between the community's interests and the legitimate interests of any individual.

\section{Traditional Societies}

Traditional societies are communal, status-based societies, governed according to principles and practices held to be fixed by tradition. They are usually ethnically homogeneous and agricultural, and frequently stateless. In traditional society, one's worth, rights, and responsibilities arise from and remain tied to differential membership in a particular society, with unequal, status-based privileges and duties resting on age, sex, caste, or other ascriptive hierarchies. The idea that one is entitled to equal concern and respect and a wide range of inalienable personal rights simply because one is a human being is utterly foreign to traditional societies. Only certain kinds of people are defined as moral persons, that is, human beings.
Although most people in traditional societies have at least some rights and privileges, these are contingent on the proper fulfillment of social roles, rather than basic personal rights held against society. Even within the recognized social boundaries, some people may be defined as outsiders, as nonbelievers are defined in strict Islamic societies, or ethnic strangers in traditional Africa. The relationship between the individual (if he or she may be so called) and society is by definition nonconflictual; everyone's interests are incorporated into the higher value system represented by the politicalreligious-legal decision makers. Man and society are assumed to be inseparable. The very idea of inalienable individual rights held equally by all against the community is, if comprehensible, likely to be viewed with horror (cf. Legesse, 1980, p. 124).

In traditional societies, there is no notion of the autonomous individual. One's worth, even one's existence, is defined by one's place, one's role in the community; apart from the community, one does not exist, or at least such an existence is largely without moral value. One's dignity - which usually is conceived primarily as an attribute of one's kinship, age, sex, or occupational group-is obtained or validated by discharging the (traditionally defined) duties of one's station, rather than by autonomously creating or unfolding a unique individual existence. In traditional society, there are neither human beings, in the relevant moral sense, nor equal, inalienable, and universal rights.

Many traditional societies were slave or caste societies; few were subject to democratic control in even a very loose sense of that term. Individual deviations from communal norms usually were harshly repressed, and women and outsiders usually were treated as inferior beings. Nonetheless, in theory at least, and often in practice as well, a certain sort of dig- 


\section{Human Dignity, Human Rights, Political Regimes}

nity, tied to the proper fulfillment of social roles, could be achieved by most people. Furthermore, social responsibilities usually were coupled with reciprocal social and economic protections. In traditional societies most people had a defined, secure, and (within its own terms) dignified place in society.

Therefore, one can at least understand, and perhaps even contextually justify, traditional society's denial of human rights. One might even argue that the traditional conception of human dignity is superior to that of liberalism. For example, it might be argued that most people prefer regulated, secure social roles, with their concomitant sense of belonging, to autonomy and its attendant insecurities. Insider "individuals" may well have fared better in many ways as part of traditional society than as, say, a textile worker in mid-nineteenth century England or South Korea today.

Such arguments, however, are not human rights arguments. To defend traditional society is to reject a society based on equal, inalienable, universal personal rights in favor of a status-based society. To prefer traditional society to liberalism is to reject a society of equal and autonomous individuals with inalienable personal rights in favor of a society of unequal, regulated occupants of social roles, incorporated into the community. Traditional society and human rights cannot be combined without violence to both (cf. Donnelly, 1982a and Howard, 1986, ch. 2).

\section{Communism}

By communism we mean an ideal type regime modeled on the structure and official ideology of contemporary Soviet bloc countries. The key feature of such societies is a communist party-state committed to total, revolutionary transformation of social and personal life. The connection between such regimes and the writings of Marx or the "authentic" Marx- ist tradition is an issue that cannot, and certainly need not, be addressed here. Our concern instead is with the frequently encountered argument that communist regimes are entirely consistent with international human rights norms.

While there are striking similarities between traditional and communist societies, especially in the submergence of the individual to the community (state) and in the use of social (class) roles to define individual worth, there are no less striking differences. Traditional societies have at most a rudimentary state apparatus, whereas in communist societies the state is the central social institution, despite ideologically obligatory references to its withering away. Rather than the often more or less face-to-face relations of small traditional society, communist societies range in size from millions to over a billion people. Instead of a relatively simple division of labor, they have a complex industrial division of labor, and rather than an ethnically homogeneous community, often bound together by real or mythic kinship ties, most communist countries are multi-ethnic.

This alters the entire texture of social relations. The communist state simply cannot be the functional equivalent of the traditional community; it necessarily appears as a distant, separate institution, incapable of providing the social and psychological support of close-knit traditional communities. Therefore, being subsumed into the "community" is quite a different process in communist societies.

While in traditional society the individual is never fully differentiated from the group, in communist societies individuals have been thoroughly differentiated. The modern economy, with its complex division of labor and extensive rolesegmentation, necessarily produces economically, and thus socially, distinct individuals, and state bureaucracies are structured to deal (only) with (anonymous or interchangeable) individuals. 


\section{American Political Science Review Vol. 80}

The political task for communist regimes, therefore, is to reabsorb the individual into the (state) society. The primacy of the state/society therefore must be politically created-as is underscored by the very project of revolutionary social transformation. One must be made a part of the community in communist societies.

However, since the basic socioeconomic organization of life under communism continues to (re)produce differentiated individuals, the process of (re)incorporation must be constantly repeated. Undifferentiated economic reincorporation is impossible, however, and ideological reincorporation, no matter how hegemonic, is insufficient. Direct political coercion, therefore, is a feature of communist collectivism that generally is absent from traditional society (because of the effectiveness of other means of social control).

As the task of the state/party/proletariat is to transform all aspects of social existence, private life is not merely subject to public regulation, but must be made public, and regulated by the state, if the revolution is to succeed. Those who follow a bourgeois or otherwise reactionary road are entitled to neither respect nor concern; at best they are ignored, and more often they are actively repressed. As one East German scholar states, "there is no freedom for enemies of the people" (Klenner, 1984, p. 15), who are defined as social outsiders. Such a belief readily leads to the identification and repression of pariah social classes and, in extreme cases, class-based "genocide" directed against kulaks or similar class enemies (Kuper, 1981, pp. 99-100).

The ethnic homogeneity of traditional society is replaced by class homogenization. "Class position," however, means simply conformity to behavioral norms specified by the state. Equality, rather than a fundamental and inviolable moral fact, is reduced to mere social sameness. In communist societies, one is equal not by birth or by nature, but only to the extent that one is essentially indistinguishable from one's fellow communist citizens, an embodiment of the new communist man. Communist societies thus produce a distinctive sort of homogenized, de-individualized person.

Communist societies obviously must violate a wide range of civil and political rights during the revolutionary transition, and necessarily, not merely as a matter of unfortunate excesses in practice. Even after communism is achieved, the denial of civil and political rights remains necessary to preserve the achievements of the revolution. The permanent denial of civil and political rights is required by the commitment to build society according to a particular substantive vision, for the exercise of personal autonomy and civil and political rights is almost certain to undermine that vision.

Furthermore, communist regimes, for all their achievements in providing economic and social goods and services, are fundamentally incompatible with economic and social rights. In communist societies, the possession and enjoyment of all rights are contingent on the discharge of social duties. For example, Article 59 of the Soviet Constitution (1977) states that "the exercise of rights and liberties is inseparable from the performance by citizens of their duties" (cf. Burlatsky, 1982; Egorov, 1979, p. 39). Thus, for example, access to higher education and desirable jobs is closely linked to political connections or behavior. Few rights of any sort are secure in such a regime, and no human rights, in the strong sense of equal and inalienable entitlements of all individuals, can be recognized.

It is important to stress the difference between having a human right and merely enjoying the substance of a right; between, for example, having food and having a right to food, or speaking freely and enjoying a right to free speech. In communist (and other communitarian) socie- 


\section{Human Dignity, Human Rights, Political Regimes}

ties, one may be guaranteed the substance of certain human rights (Shue, 1980, pp. 75-76) -that is, goods, services, and opportunities may be enjoyed. They are not, however, enjoyed as rights; those who conform receive certain benefits, but the state may freely bestow or withdraw these as it sees fit (cf. Donnelly, 1985, pp. 11-12, 52-53, 77-80). This is as true of economic and social rights as civil and political rights. One is not entitled to these benefits simply as a human being, one does not have the special control provided by possession of a right, and one's claims to enjoy these benefits do not have the force of human rights.

In communist regimes, in fact, even as a citizen one is entitled to nothing from the state: "Human rights ... do not exist outside the state or against the state. The state is their creator" (Lopatka, 1979, p. 7; cf. Weichelt, 1979, p. 3). Rights are acquired only by the discharge of class obligations, as defined by the state (Lieberam, 1979, p. 14). Social outsiders, such as landowners or the bourgeoisie, may lose not only their former property rights, but also all other rights.

Communist society thus rests on a social utilitarianism fundamentally incompatible with human rights. The good of society, as determined by the state/ party, always takes precedence over all else. Because individual "rights" must always yield to social purposes, as enunciated by the state, such "rights" are worthless; no matter what the state does, it cannot be held guilty of violating them. Whatever the benefits and opportunities citizens may (contingently) receive-and they are undeniably substantial in some communist regimes-communism represents a thorough denial of human rights.

\section{Corporatism}

Corporatism, a principal form of contemporary right-wing regimes, can be defined as

\begin{abstract}
a system of interest representation in which the constituent units are organized into a limited number of single, compulsory, non-competitive, hierarchically ordered and functionally differentiated categories, recognized or licensed (if not created) by the state and granted a deliberate representational monopoly within their respective categories in exchange for observing certain controls on their selection of leaders and articulation of demands and support. (Schmitter, 1974, pp. 93-94)
\end{abstract}

Corporatist regimes present themselves as neutral instruments to regulate and mediate the antithetical interests of labor and capital, with other groups-such as women and youth-often officially organized and incorporated into the political structure as well, further undercutting basic structural conflicts. In practice, however, class rule is unambiguously at the heart of corporatism. The essential purpose of its ideology and political structure is to prevent further class conflict and entrench the extant economic hierarchy.

The state proclaims the equal dignity of all segments of society. Meanwhile, unequal private power and property accumulate. Workers and peasants are not necessarily excluded from a share of social benefits-for example, state controlled trade unions may be allowed to pursue certain improvements in working conditions or living standards, so long as class conflicts are denied-but they benefit only inadvertently or as a side-payment to co-opt potential opponents of the ruling corporate coalition. Equal concern and respect is at best ignored.

One variant of corporatism, which can be called authoritarianism for want of a better term, preserves an important sphere of private autonomy and activity. Religion and education, for example, may be left as a private matter. This privacy, however, is only a realm of public indifference. It is quite different from positive respect for or protection of a right to privacy and related human rights. Privacy (of thought, religion, belief) is not so much protected in authoritarian regimes as it is ignored-and it is ignored only as 


\section{American Political Science Review Vol. 80}

long as it does not interfere with the basic corporatist bargain. Personal autonomy is, at best, not a right but a contingent benefit.

The fascist variant of corporatism, however, is actively hostile to the private. In reaction to what it views as the unabated individualism of liberal society, fascism proclaims a romantic ideology of (mythic) consensus, homogeneity, and personal comfort in conforming to social roles. Human dignity is to be achieved through integration into an allencompassing moral order, represented by the fascist state. Much as in communism, any challenge to this order, including deviation in personal values and beliefs, is treated as a threat to the entire social fabric.

This ideology of the primacy of the state readily leads to terror and scapegoating. Nonviolent denials of civil and political right are likely to be inadequate to prevent independent "political" activity, now redefined to include much of "private" personal life. Direct terror is likely to be necessary; so also is the creation and persecution of outsider or scapegoat groups, in extreme cases culminating in genocide. Such persecution not only allows the state to displace real social tensions arising from the corporatist character of society, but, in the very denial of the rights of the scapegoat group, reaffirms the unity of the fascist individual, society, and state.

From a human rights perspective, however, fascism is merely the extreme form of corporatism; fascism may actively violate more rights, but authoritarian corporatism is unlikely to protect many more. One cannot even assuredly say that life is preferable for the average individual in authoritarian corporatism; for example, if public indifference results in anomie, the intense feeling of belonging espoused by fascism may seem preferable, at least for insiders. In any case, authoritarian corporatism's public indifference to the bulk of society is certainly a denial of equal concern, while its denial of independent political action is incompatible with equal respect. Whatever the form, corporatism denies inherent personal dignity and equal concern and respect in the very bargain that defines the regime.

\section{Development Dictatorship}

One further type of communitarian regime, which we call development dictatorship, should be briefly noted. In development dictatorships, the principal resource of the ruling elite is control of the means of coercion, justified in the name of the most rapid possible economic development. Development, which has achieved an unprecedented ideological hegemony in the Third World, is easily presented as the moral equivalent of war, requiring the subordination of the individual to the state. Therefore, in the hands of repressive elites it nicely justifies a wide range of human rights violations, especially since the connection between particular violations and underlying development goals is likely to be at best very loosely defined.

Development dictatorship is distinguished from corporatism or communism in large measure by its class structure. In development dictatorships, economic class position is less the source of power than the result of control of the state. In nationalized economies, the organizational (Markovitz, 1977, ch. 6) or bureaucratic (Shivji, 1976, pt. 3) "bourgeoisie" is composed of occupants of high-level office in the military, the government, the bureaucracy, or the ruling party. A parasitic private bourgeoisie, essentially living off its economic relations with the state, may also exist. Controlled by members of these various elites, who have few resources other than coercion to maintain their power, development dictatorships frequently degenerate in cycles of coups and countercoups, or, once stabil- 


\section{Human Dignity, Human Rights. Political Regimes}

ized, evolve into some sort of corporatist regime. The regime rests lightly on top of society, rather than being a political representation of deep underlying socioeconomic forces (cf. Hyden, 1983, ch. 2).

Even where the regime's commitment to development is genuine, rather than merely a cover for elite depredations-so that there is an attempt to provide the substance of some economic and social rights-enshrining development as an overriding social objective assures that individuals and their rights will regularly be ignored. The value put on privacy tends to be low, as private goals might interfere with national development goals. The identification of "outsiders," economic saboteurs, or similar scapegoat groups is a common diversionary tactic when development plans fail. Full personal dignity is conceived largely as an abstract future good, to be realized only after success in the struggle for development. In general, individual human rights, especially rights against the state, the essential agent of development, must wait until development has been achieved. Once more, we are faced with a choice between human rights and alternative social goals based on a radically different conception of human dignity.

\section{Communitarianism and the Impossibility of Human Rights}

Whether communitarianism is forward or backward looking, it is structurally, ideologically, and philosophically incompatible with human rights. The view of human dignity found in all communitarian societies is that the individual realizes himself as part of the group by unquestioningly filling his social role or being loyal to the state. This conception of human dignity is incompatible with human rights.

At the core of this incompatibility is the denial of social value to personal autonomy and privacy. In communitar- ian societies the state (or traditional authorities), as the representative of society, must control family life, religion, education, and all other potentially independent aspects of life. Any institution that might influence or challenge the reigning regime and its ideology must be eradicated, or at least regulated; often one's very beliefs, and certainly all aspects of one's behavior, are treated as legitimate matters for social regulation.

When personal autonomy is thus denied-even repressed as a threat to society-moral equality must also be denied; some people-those who "fit in"-are treated as more worthy of concern or respect than others. The full range of international human rights must thereby be violated.

The rule of law and procedural due process are obviously incompatible with such regimes; pursuit of the community's substantive goals overrides "mere procedures." Due process is also rejected because it suggests that political organs representative of the full community might treat citizens unfairly, a possibility denied by the communitarian premise of the regime. Equal protection of the laws, and nondiscrimination more broadly, also are incompatible with communitarian regimes. In fact, positive discrimination against social deviants is essential to the political pursuit of unity; differences between individuals or groups (other than those that are officially sanctioned) are not to be protected-let alone valued as expressions of autonomy-but rather repressed, or at best ignored. In communitarian regimes, one is entitled to the protection of the laws and a guaranteed share of social resources and opportunities only to the extent that one fits within certain substantive, ideologically defined categories.

Political participation is similarly restricted, both in its substance and its participants. Debate over fundamental social and political aims cannot be al- 
Table 1. Social Conceptions of Human Dignity: A Typology

\begin{tabular}{llllll}
\hline \hline Regime Type & $\begin{array}{l}\text { Autonomy vs. } \\
\text { Role Fulfillment }\end{array}$ & $\begin{array}{l}\text { Conflict vs. } \\
\text { Consensus }\end{array}$ & $\begin{array}{l}\text { Repression } \\
\text { of Outsiders }\end{array}$ & $\begin{array}{l}\text { Valuation } \\
\text { of Privacy }\end{array}$ & $\begin{array}{l}\text { Equality vs. } \\
\text { Hierarchy }\end{array}$ \\
\hline Liberal & Autonomy & Conflict & No & High & Equality \\
Minimal & Autonomy & Conflict & No (?) & Very high & Hierarchy \\
Traditional & Roles & Consensus & Yes & Very low & Hierarchy \\
Communist & Roles & Consensus & Yes & Very low & Equality \\
Corporatist & Roles & Consensus & Yes & Low & Hierarchy \\
Developmental & Roles & Consensus & Yes (?) & Low & Equality \\
\hline
\end{tabular}

lowed, because they are already set by tradition or the reigning ideology. Likewise, politics is dominated by a small elite, chosen by ascription, restricted party membership, or other nondemocratic means-or, where the forms of democratic politics are utilized (e.g., communism), real control lies elsewhere (e.g., a vanguard party).

Many communitarian societies, however, do perform relatively well in providing the substance of economic rights. Many espouse, and some do achieve, relative equality of material circumstances and a basic floor of material security. But such economic "rights" are mere benefits, contingent on approved membership in the political community and on the performance of social duties. Citizens are not entitled to these goods and services; at most they may petition for them, not claim them as rights. Material security certainly is valuable, whether it is a right or a privilege, but such "security" is precariously insecure in the absence of human rights held against the state, since it can be taken away as easily as it is granted.

In sum, communitarian regimes fall short of the standard of human rights in all major areas. Much as liberalism is necessarily committed to protecting, implementing, and fostering the enjoyment of the full range of internationally recognized human rights, communitarian regimes necessarily violate the full range of human rights.

\section{Human Dignity, Human Rights, and Political Regimes}

We can pull together this discussion in a typology of social conceptions of human dignity. Table 1 lists the positions of our six types of regimes on five sociopolitical variables shown in the discussion above to be important to the social definition of human dignity. It is immediately apparent from the first four columns that these regimes fall into two broad classes, individualistic (liberal and minimal) regimes and communitarian (traditional, communist, corporatist, and developmental) regimes.

Not surprisingly, the first four variables are rather closely related. Society's attitude towards autonomy is especially important. A commitment to personal autonomy requires accepting a certain degree of social conflict, largely precludes enforcing the substantive models of belief and behavior that are the basis for the repression of outsiders, and leaves open a considerable realm of valued private activity. Likewise, a stress on role fulfillment implies a consensual society: roles are defined so as to produce consensus when properly performed; "outsiders" (those without approved or valued roles) are repressed; and privacy, which exists outside of predefined roles, is not socially valued.

There are, however, no less important differences within each of these two classes of regimes. Liberalism's commit- 
1986 Human Dignity, Human Rights, Political Regimes

Table 2. Social Conceptions of Human Dignity and Human Rights Performance

\begin{tabular}{|c|c|c|c|c|}
\hline Regime Type & $\begin{array}{l}\text { Equality or } \\
\text { Hierarchy }\end{array}$ & $\begin{array}{l}\text { Valuation of } \\
\text { Belonging }\end{array}$ & $\begin{array}{l}\text { Civil and } \\
\text { Political Rights }\end{array}$ & $\begin{array}{l}\text { Economic and } \\
\text { Social Rights }\end{array}$ \\
\hline $\begin{array}{l}\text { Individualistic Reg } \\
\text { Liberal } \\
\text { Minimal }\end{array}$ & $\begin{array}{l}\text { Equality } \\
\text { Hierarchy }\end{array}$ & $\begin{array}{l}\text { Moderate } \\
\text { Very low }\end{array}$ & $\begin{array}{l}\text { Yes } \\
\text { Yes }\end{array}$ & $\begin{array}{l}\text { Yes } \\
\text { No }\end{array}$ \\
\hline $\begin{array}{l}\text { Communitarian } R \\
\text { Traditional } \\
\text { Communist } \\
\text { Corporatist } \\
\text { Developmental }\end{array}$ & $\begin{array}{l}\text { Hierarchy } \\
\text { Equality } \\
\text { Hierarchy } \\
\text { Equality }\end{array}$ & $\begin{array}{l}\text { Very high } \\
\text { High } \\
\text { Varies } \\
\text { Moderate (?) }\end{array}$ & $\begin{array}{l}\text { No } \\
\text { No } \\
\text { No } \\
\text { No }\end{array}$ & $\begin{array}{l}\text { Substance only } \\
\text { Substance only } \\
\text { No (?) } \\
\text { Substance (?) }\end{array}$ \\
\hline
\end{tabular}

ment to autonomy is matched by a commitment to equality; human dignity, for the liberal, requires the union of autonomy and equality. This commitment to equality further strengthens the tendency not to repress outsiders, or even to define outsider groups other than noncitizens, who are ignored rather than repressed.

In contrast, those at the bottom of the minimal state's social hierarchy are denied economic and social rights, as a result of the absence of a commitment to equality and the presence of an extremely high valuation of privacy (especially private economic activity) under minimalism. Thus, they may be seen as indirectly oppressed economic outsiders, and if the lower classes attempt to challenge this denial of economic and social rights, direct repression is likely. Furthermore, whereas liberalism merely accepts a certain amount of social conflict as an unavoidable consequence of personal autonomy, and even tempers conflict by the pursuit of social and economic equality, minimalists tend to view social conflict in no worse than neutral terms, and even as desirable competition between unequal, atomistic individuals.

There are also important differences among communitarian regimes. For example, there are considerable differences in the substantive bases used for the definition of social membership and roles. The most important differences, though, concern the valuation of equality and belonging (the obverse of privacy), as we can see in Table 2, which correlates the major determinants of social conceptions of human dignity with the human rights performance of each type of regime.

All communitarian regimes reject civil and political rights, which can be recognized only when individual autonomy is valued over role fulfillment. However, traditional and communist regimes, one hierarchical, the other egalitarian, do provide the substance of (at least some) economic and social rights (for insiders); that is, they provide goods, services, and opportunities, but without the power or control that comes with enjoying these benefits as rights. The value placed on equality then largely determines the range and distribution of these benefits. Communist regimes are committed to providing them equally, and in great and ever increasing quantity. Hierarchical traditional regimes, however, guarantee only a minimum floor for all (or at least all but chattel slaves, untouchables, and similar near-outsider groups).

Corporatist and developmental regimes-again, one hierarchical, the other egalitarian-do not generally offer even this much. The typical (authoritarian) corporatist regime protects only the interests of the ruling coalition (although fascist corporatism is likely to provide at least some economic and social 


\section{American Political Science Review Vol. 80}

benefits to all insiders-thus the questionable "no" in Table 2). Developmental regimes are ideologically committed to providing the substance of economic and social rights for all (insiders), at least in the long run, but since the social composition of such regimes usually belies and precludes the realization of this commitment, it remains of at best questionable practical significance.

This suggests that at least as important a variable as equality or hierarchy is the valuation of belonging. Traditional and communist regimes highly value belonging, and thus provide the substance of many social and economic rights to all insiders, while corporatist and developmental regimes, which do not guarantee even the substance of economic and social rights, place lower value on a sense of belonging. This conclusion is also implied by the comparison of liberal and minimal regimes. The absence of economic and social rights in minimal regimes is explained not simply by the absence of a social commitment to equality, but also by the very low valuation of belonging.

Only when autonomy, equality, and at least a moderately high value on belonging are combined-as in liberalism-do we find a commitment to economic and social rights, and not just their substance. Only with a commitment to personal autonomy will a regime actively protect civil and political rights. In other words, only in a liberal regime can there be a fundamental political commitment to the full range of internationally recognized human rights.

Other social systems may claim to have competing views of human rights. They do not. Rather, they rest on competing views of human dignity, all of which deny both the centrality of the individual in political society and the (human) rights of men and women to make, and have enforced, equal and inalienable civil, political, economic, and social claims on the state. Only liberalism, understood as a regime based on the political right to equal concern and respect, is a political system based on human rights.

\section{Note}

We thank Paul Brietzke, Edward Kent, Jane Sweeney, and the Comparative Politics Study Group at the University of North Carolina for comments on earlier drafts. Rhoda Howard also thanks the Social Sciences and Humanities Research Council of Canada for funds enabling her to carry out research for this article. An earlier version was presented at the annual conference of the International Studies Association, Washington, D. C., March 6, 1985.

\section{References}

Burlatsky, F. M. et al. 1982. The Rights of the Individual in Socialist Society. Moscow: Progress Publishers.

Buultjens, Ralph. 1980. Human Rights in Indian Political Culture. In Kenneth W. Thompson, ed., The Moral Imperatives of Human Rights: A World Survey. Washington, D.C.: University Press of America.

$\rightarrow$ Donnelly, Jack. 1982a. Human Rights and Human Dignity: An Analytic Critique of Non-Western Human Rights Conceptions. American Political Science Review, 76:303-16.

$\rightarrow$ Donnelly, Jack. 1982b. Human Rights as Natural Rights. Human Rights Quarterly, 4:391-405.

Donnelly, Jack. 1985. The Concept of Human Rights. London: Croom Helm; New York: St. Martin's Press.

Dworkin, Ronald. 1977. Taking Rights Seriously. Cambridge: Harvard University Press.

Dworkin, Ronald. 1985. A Matter of Principle. Cambridge: Harvard University Press.

Egorov, Anatolii Grigorevich. 1979. Socialism and the Individual: Rights and Freedoms. Soviet Studies in Philosophy, 18:3-51.

Goldstein, Robert Justin. 1983. Political Repression in Nineteenth Century Europe. Totowa, NJ: Barnes and Noble.

Graefrath, Bernhard. 1983. Implementation of International Standards on Human Rights. GDR Committee for Human Rights Bulletin, no. 3:3-42.

Gros Espiell, Hector. 1979. The Evolving Concept of Human Rights: Western, Socialist and Third World Approaches. In B. G. Ramcharan, ed., Human Rights: Thirty Years After the Universal Declaration. The Hague: Martinus Nijhoff.

Howard, Rhoda. 1986. Human Rights in Common- 


\section{Human Dignity, Human Rights, Political Regimes}

wealth Africa. Totowa, NJ: Rowman and Allanheld.

Hyden, Goran. 1983. No Shortcuts to Progress: African Development Management in Perspective. Berkeley: University of California Press.

International Covenant on Economic, Social and Cultural Rights and International Covenant on Civil and Political Rights. 1966. See United Nations, 1966.

Khushalani, Yougindra. 1983. Human Rights in Asia and Africa. Human Rights Law Journal, 4:403-442.

Klenner, H. 1984. Freedom and Human Rights. GDR Committee for Human Rights Bulletin, no. 10:13-21.

Kuper, Leo. 1981. Genocide: Its Political Use in the Twentieth Century. Harmondsworth, Middlesex: Penguin Books.

Legesse, Asmarom. 1980. Human Rights in African Political Culture. In Kenneth W. Thompson, ed. The Moral Imperatives of Human Rights: $A$ World Survey. Washington, D.C.: University Press of America.

Lieberam, Ekkehard. 1979. Criticism of Bourgeois Attacks on Basic Rights in Socialism. GDR Committee for Human Rights Bulletin, no. 3:12-23.

Lopatka, Adam. 1979. On the Notion of Human Rights. GDR Committee for Human Rights Bulletin, no. 4:5-11.

Marasinghe, Lakshman. 1984. Traditional Conceptions of Human Rights in Africa. In Claude E. Welch, Jr. and Ronald I. Meltzer, eds., Human Rights and Development in Africa. Albany: State University of New York Press.

Markovitz, Irving Leonard. 1977. Power and Class in Africa. Englewood Cliffs, NJ: Prentice-Hall.

Mojekwu, Chris E. 1980. International Human Rights: The African Perspective. In Jack L. Nelson and Vera M. Green, eds., International Human Rights: Contemporary Issues. Stanfordville, NY: Human Rights Publishing Group.

Nozick, Robert. 1974. Anarchy, State and Utopia. New York: Basic Books.
Pollis, Adamantia. 1982. Liberal, Socialist and Third World Perspectives on Human Rights. In Adamantia Pollis and Peter Schwab, eds., Towards a Human Rights Framework. New York: Praeger Publishers.

Ruffin, Patricia. 1982. Socialist Development and Human Rights in Cuba. In Adamantia Pollis and Peter Schwab, eds., Towards a Human Rights Framework. New York: Praeger Publishers.

Schmitter, Phillipe C. 1974. Still the Century of Corporatism? Review of Politics, 36:85-131.

Shivji, Issa G. 1976. Class Struggles in Tanzania. London: Heinemann.

Shue, Henry. 1980. Basic Rights: Subsistence, Affluence and U.S. Foreign Policy. Princeton: Princeton University Press.

Soviet Constitution. 1977. Current Digest of the Soviet Press. 29:1-13.

Stackhouse, Max L. 1984. Creeds, Society and Human Rights: A Study in Three Cultures. Grand Rapids, MI: William B. Eerdmans.

United Nations. 1948. Universal Declaration of Human Rights. U.N. General Assembly Resolution 217A(III), A/810, 10 December.

United Nations. 1966. International Covenant on Economic, Social and Cultural Rights and International Covenant on Civil and Political Rights. U.S. General Assembly Resolution 2200(XXI), A/6316, 16 December.

Universal Declaration of Human Rights. See United Nations, 1948.

Weber, Max. 1946. From Max Weber: Essays in Sociology. Hans Heinrich Gerth and C. Wright Mills, eds. New York: Oxford University Press.

Weichelt, Wolfgang. 1979. Some Observations on the Notion of Human Rights. GDR Committee for Human Rights Bulletin, no. 2:3-15.

Wiarda, Howard J. 1982. Democracy and Human Rights in Latin America: Toward a New Conceptualization. In Howard J. Wiarda, ed., Human Rights and U.S. Human Rights Policy. Washington, D.C.: American Enterprise Institute.

Rhoda E. Howard is Associate Professor of Sociology, McMaster University, Hamilton, Ontario L8S 4M4.

Jack Donnelly is Assistant Professor of Political Science, University of North Carolina, Chapel Hill, NC 27514. 